\title{
Investor Beliefs Revision In The Multiple Benchmark Accounting Information
}

\author{
Riza Praditha ${ }^{1}$, Abdul Hamid Habbe ${ }^{2}$, Robert $\mathrm{Jao}^{3}$ \\ ${ }^{1}$ Jurusan Akuntansi, STIE Tri Dharma Nusantara Makassar, Indonesia \\ ${ }^{2}$ Fakultas Ekonomi dan Bisnis, Universitas Hasanuddin Makassar, Indonesia \\ ${ }^{3}$ Fakultas Ekonomi dan Bisnis, Universitas Atma Jaya Makassar, Indonesia \\ E-mail : rizapradithaa@gmail.com
}

Revised: 05/06/2020 Published: 30/06/2020

\begin{abstract}
Abstrak. Tujuan penelitian ini adalah untuk menguji efektivitas dari pengungkapan informasi akuntansi Multiple Benchmark terhadap revisi keyakinan investor dalam memprediksi kinerja laba masa depan. Desain penelitian yang digunakan adalah eksperimen laboratorium $2 x 2$ full factorial within subject. Subjek yang digunakan dalam penelitian ini adalah 20 orang mahasiswa Program Doktor Ilmu Ekonomi Universitas Hasanuddin yang diproksikan sebagai investor. Hasil penelitian menunjukkan bahwa ketika investor memeroleh informasi laba transitory bernilai positif investor cenderung melakukan revisi atas prediksi laba yang dilakukan berdasarkan informasi tambahan (Management Guidance). Hal tersebut ditunjukkan adanya perbedaan yang signifikan antara prediksi laba sebelum dan setelah diberikan informasi tambahan. Sedangkan, ketika investor memeroleh informasi laba transitory bernilai negatif, menunjukkan hasil yang sebaliknya. Investor cenderung memprediksi kinerja laba masa depan tidak jauh berbeda dari keyakinan awalnya. Hal ini menunjukkan adanya keterpatokan terhadap nilai awal yang menyebabkan investor mengalami bias heuristik anchoring-adjustment.
\end{abstract}

Kata kunci: Informasi Akuntansi, Multiple Benchmark, Kinerja Laba, Anchoring-adjustment.

\begin{abstract}
Aims of this study to examine the effectiveness of the disclosure of Multiple Benchmark accounting information on the investor's belief revision in predicting future earnings performance. The research design used laboratory experiments $2 \times 2$ full factorial within-subject. The subjects used in this study were 20 students of the Doctoral Program in Economics, Hasanuddin University who were proxied as investors. The results show that when investors obtain information on temporary earnings is positive, investors tend to revise earning predictions based on additional information (Management Guidance). This is indicated by the significant difference between earnings predictions before and after additional information is provided. Meanwhile, when investors get information about negative temporary earnings, the results show the opposite. Investors tend to predict future earnings performance that is not much different from their initial beliefs. This shows the existence of a set of initial values that cause investors to experience anchoring-adjustment heuristic bias.
\end{abstract}

Keywords: Accounting Information, Multiple Benchmark, Earnings Performance, Anchoring-adjustment.

\section{Introduction}

The concept of belief-adjustment theory (Hogarth \& Einhorn, 1992) forms the basis of this research, in which this concept suggests that there are individual reactions to orders and timings for two different information. This theory explains that when there is two information with different information content such as good news and bad news, investors tend to revise their initial beliefs. This model explains that the way a person improves his initial beliefs is influenced by various factors. Some of the characteristics considered in this concept are direction, strength, and type. 
Direction indicates the presence or absence of changes in belief in predictions or decisions taken. Strengths related to the strengths and weaknesses of information patterns influence decisions. Whereas type is a reflection of information patterns both positive, negative, or mixed information patterns (Wardhani \& Almilia, 2012; Anggraeni \& Almilia, 2017). The belief adjustment theory explains that the factors causing recency effects are anchoring or prior beliefs.

Anchoring is the initial belief. The theory says that high anchoring (low) will decrease (increase) when faced with negative (positive) information when compared to low (high) anchoring (Hartono, 2004; Habbe dan Mande, 2016). Anchoring Heuristic describes the phenomenon where information greatly influences decisions, especially information that is found at the beginning of a particular situation (Richie dan Josephson, 2017). The anchoring effect in a decision has a strong influence and can last long enough even after making irrational decisions. The anchoring effect can occur even if the anchoring value is not informative or unreasonable (Bahník et al., 2017).

The accounting information used in this study is Multiple Benchmark information which is a method of information disclosure that considers more than one benchmark, namely past earnings or historical earnings and future information in the form of management guidelines (Management Guidance). This form of information is based on Multiple Reference-Point Theory (Fiegenbaum et al., 1996; Ordóñez et al., 2000) which explains that three main dimensions influence individual decision making, namely internal, external and time dimensions. The time dimensions of both past, present and future are reflected in past earnings information and current earnings information. Besides, this form of information also shows the existence of future information both internally and externally that is reflected in the Management Guidance.

This strategy includes an explanation of the usefulness of accounting information that is mandatory and voluntary in nature, internal and external information, past and future information, quantitative and qualitative information. Strategy Management guidelines consist of some internal information such as product, service and organizational issues, as well as external information in the form of economic conditions and government regulations (Wahyuni \& Hartono, 2012; Wahyuni et al., 2016).

This research is important because it is well known that in the investment world or the Capital Market there are known types of investors who are rational and irrational. Rational investors are investors who focus on the relationship between risk and expected return. While irrational investors are investors who tend to be influenced by other factors such as psychological factors in this case are cognitive and emotional so that they often cause bias (Anggraeni \& Almilia, 2017). The form of Multiple Benchmark information is present as one solution to reduce the bias tendencies experienced by irrational investors (Praditha et al., 2020).

This form of information is said to be more effective in describing the company's performance (Schrand \& Walther, 2000; Krische, 2005; Han \& Tan, 2007; Wahyuni et al., 2016; Praditha et al., 2020) to make investors better able to predict everything considerations and 
decisions to be taken. Besides, the lack of research that uses the Multiple Benchmark information form motivates this research to be carried out. In Indonesia alone, the disclosure of this form of Multiple Benchmark information was previously tested by Wahyuni et al., (2016). Therefore, this study developed Wahyuni et al., (2016) research by using a different experimental method, namely the experimental laboratory. Testing with laboratory design is carried out to strengthen the internal validity of the treatment given. This is done because the main purpose of this study is to prove the effectiveness of Multiple Benchmark information in the process of revising investor confidence in predicting the future earnings performance of a company. Investor's belief revision is generally influenced by psychological factors, in this case, heuristic psychology. At the very least, investors experience an initial value or initial belief in making consideration or making investment decisions (Bloomfield et al., 2003; Habbe \& Mande, 2016; Habbe, 2017; Richie \& Josephson, 2017; Praditha et al., 2020).

\section{Research Method}

\section{Research Design}

The design of this study was a full factorial within-subject 2 × 2 laboratory experiment. The factors used are two information loads (positive and negative) as well as two forms of information (single and multiple benchmarks).

Table 1. Research design $2 \times 2$ full factorial

\begin{tabular}{lll}
\hline Information Loads & \multicolumn{2}{c}{ Information form } \\
\hline Positive & Single & Multiple \\
Negative & Single & Multiple \\
\hline
\end{tabular}

Source: Dara Processed

Table 1 shows the experimental design with the description of information loading factors and the form of information. Information load is positive which means it has a transitory profit (profit) value and a negative value which means it has a transitory loss value. While the form of information consists of two, namely the form of information single and multiple benchmarks. The single benchmark is accounting information in the form of past period earnings and current period earnings. Whereas Multiple Benchmark information that contains past period earnings, current period earnings, and Management Guidance.

\section{Experimental Procedure}

The subjects used in this study were 20 students of the Doctoral Program in Economics who were proxied as investors. Each investor is given a draft containing an experimental treatment in which, the initial stage the investor is asked to fill in data relating to self-identity. After that, investors are asked to read the financial statements presented in the form of a single benchmark based on instructions. Investors are then asked to predict the company's future earnings. 
Furthermore, investors are instructed to read the financial statements presented in the form of Multiple Benchmarks, then asked to answer the question of whether to change their predictions or remain on the previous predictions, if "yes" investors are required to write values to predict new earnings.

\section{Treatment dan Manipulation Checks}

The treatment used is the development of the treatment used by Wahyuni et al. (2016) by adjusting the manipulation of variables in this study. Manipulation checks use a binary questionnaire (true or false) of three questions to ensure that the subject understands the assignment given. These three questions relate to the form of information presented, the form of assignments provided, and the types of benchmarks used. Error in answering the question, it is considered a failure in checking manipulation.

\section{Analysis Method}

The analysis used in this study is descriptive statistics to map the subject demographics. Furthermore, the General Linear Model - Repeated Measurement Analysis is used to test the differences in earnings predictions for each form of information.

\section{Result and Discussion}

\section{Subject Demographics}

In the initial stages of the experimental procedure, investors are asked to fill in personal data relating to gender, age, concentration/field of study, and investment experience. As additional information that the selection of subjects participating in this research is the convenience sampling method, where the doctoral program students involved are students who are willing without mapping the characteristics.

Table 2. Demographics

\begin{tabular}{llcc}
\hline & Characteristics & Amount & Percentage \\
\hline Gender & Male & 11 & $55 \%$ \\
& Female & 9 & $45 \%$ \\
\hline Ages & $<30$ y.o. & 0 & $0 \%$ \\
& $31-40$ y.o. & 15 & $75 \%$ \\
& $>40$ y.o. & 5 & $25 \%$ \\
\hline Field of study & Accounting & 7 & $35 \%$ \\
& Management & 11 & $55 \%$ \\
& Economics & 2 & $10 \%$ \\
\hline Investment & Experienced & 10 & $50 \%$ \\
Experience & Not Experienced & 10 & $50 \%$ \\
\hline
\end{tabular}

Source: Data Processed. 
Table 2 shows that there were 11 male subjects and 9 female subjects. As for the age characteristics, subjects aged between 31-40 years were the most dominant at $75 \%$, and the remaining $25 \%$ were subjected $>40$ years old. Based on the concentration or field of study, it was dominated by students in the field of management, both financial management, marketing, strategy, and human resources which amounted to 55\%. Finally, the investment experience of the subject is balanced, as many as 10 subjects have investment experience in the Capital Market, while the remaining 10 people have no experience.

\section{Manipulation Checks}

Manipulation checking aims to ensure that the subject understands well what is being assigned to the experiment. So investors who fail to check manipulation are deemed not to understand the treatment given and must be excluded from the data used.

Table 3. Manipulation Checks

\begin{tabular}{llll}
\hline \multicolumn{2}{c}{ Type of Questions (True atau False) } & Right Answer & Answer Value \\
\hline \multicolumn{2}{l}{$\begin{array}{l}\text { Financial Information contains information on } \\
\text { past earnings, current earnings, and } \\
\text { Management Guidance }\end{array}$} & 21 people & $95 \%$ \\
2 & $\begin{array}{l}\text { You are asked to predict future earnings (2020) } \\
\text { Accounting information containing the }\end{array}$ & $100 \%$ \\
3 & $\begin{array}{l}\text { profit/loss value of the sale of fixed assets } \\
\text { (transitory) }\end{array}$ & 21 people & $95 \%$ \\
\hline
\end{tabular}

Source: Data Processed

The number of participants in this experiment was 22 people, but 2 participants failed in checking manipulation and so had to be excluded from the collected data. Table 3 shows that participants who failed the manipulation check were participants who were incorrect in answering questions 1 and 3 of the binary questionnaire. In other words, only question number 2 is answered correctly by all participants and is worth $100 \%$ while the remainder is $95 \%$ each. Thus, only 20 data can be used in this experiment.

\section{Testing Differences in Prediction on Positive Information Loads}

Positive information includes information on profit or return on the sale of fixed assets (transitory profit) of Rp315,000 which is used as a benchmark. Information in the form of a single presents information on earnings for the past period (2018) of Rp.530,000 and information on the current period (2019) of Rp525,000. While the form of multiple information in addition to presenting information on past and present periods, it also presents Management Guidance information from both internal and external companies. Information Management Guidance also 
has a positive value following the pattern of information content presented. Statistical test results are shown in the table below.

Table 4. Differences in Prediction on Positive Information Loads

\begin{tabular}{lccccc}
\hline Information Form & N & Mean & $\begin{array}{c}\text { Standart } \\
\text { Deviation }\end{array}$ & F & P-Value \\
\cline { 1 - 4 } Single & 20 & 504.950 & 5898,037 & 26,944 & 0,000 \\
\cline { 1 - 4 } Multiple & 20 & 527.000 & 17576,899 & & \\
\hline
\end{tabular}

Source: Data Processed

sTable 4 shows that from 20 samples given positive information in the form of a single benchmark, the average predicted future earnings of 504,950 and then revised their beliefs to 527,000 after being given additional information in the form of Management Guidance to frame the information into Multiple Benchmarks. This change in value indicates a change in belief significantly as evidenced by the $\mathrm{p}$-value of $0,000<0.05$. This shows that investors revise their initial beliefs based on additional information obtained. These results are in line with findings (Schrand \& Walther, 2000; Han \& Tan, 2007; Wahyuni et al., 2016; Praditha et al., 2020).

Changes in predictions of future earnings performance by investors indicate the influence of the form of information presented. Investors tend to stick to information that is not repeated (transitory) and also additional information that is considered more comprehensive. The additional information presented in Management Guidance which is also of positive value has been proven to influence investors' initial beliefs in predicting the company's future earnings performance to be higher than their initial beliefs. Investors tend to evaluate the company's profit performance more favorably (more favorable) when historical earnings containing transitory earnings are revealed in the present earnings announcement (Schrand \& Walther, 2000; Krische, 2005; Han \& Tan, 2007; Wahyuni et al., 2016; Praditha et al., 2020). Thus, it can be concluded that the form of Multiple Benchmark information with a load of positive information can effectively influence the revision of investor confidence in making considerations and various investment decisions.

\section{Testing Differences in Prediction on Negative Information Loads}

Information with negative charges referred to in this experiment is the existence of information on losses from the sale of fixed assets or that are considered as transitory losses. This transitory loss becomes the benchmark in the disclosure of single benchmark information. so the information presented is the existence of past period profit value and a decrease in current period earnings due to transitory losses. Unlike the Multiple Benchmark accounting information which adds one form of information that is information in the form of Management Guidelines both from internal and external companies.

Based on the data used in the treatment, the previous period's profit information presented is Rp.425,000 and the current period information is Rp.430,000 which includes the loss value of 
fixed assets sales of Rp.315,000. The Management Guidance presented has the same charge pattern as the charge information of earnings which is negative, so information relating to the company's internal and external information that is disclosed also has a negative charge. Based on this information, investors predict the company's future earnings performance by not much different from their initial beliefs. This can be explained based on the results of the repeated measurement analysis test in the table below.

Table 5. Differences in Prediction on Negative Information Loads

\begin{tabular}{cccccc}
\hline Information Form & N & Mean & $\begin{array}{c}\text { Standar } \\
\text { Deviation }\end{array}$ & F & P-Value \\
\cline { 2 - 4 } & 20 & 426.500 & 21404,623 & 0,008 & 0,930 \\
\hline Multiple & 20 & 427.000 & 19761,739 & & \\
\hline
\end{tabular}

Source: Data Processed

Table 5 shows that investors who are given negatively charged accounting information with a single benchmark frame will predict future earnings performance with an average value of 426,500. Meanwhile, when investors are given additional information in the form of Management Guidance with the same charge (negative), then investors tend to revise their predictions higher to 427,000 (more favorable) but not much different from their initial beliefs. In other words, the predicted value of the company's future earnings performance by investors does not differ significantly between before or after additional information is given in the form of negatively charged Management Guidelines.

These results indicate that the existence of additional information in the form of Management Guidance as part of the form of Multiple Benchmark information provided to investors is not able to influence investors to change their predictions. Investors still tend to be pegged to the initial value which is believed to be an anchor. This also means that in the case of negative charges, investor predictions tend to experience heuristic bias, in this case heuristic anchoring-adjustment.

An anchoring-adjustment heuristic is where investors tend to make judgments based on past information (anchoring) and then adjust to new information obtained (Tversky and Kahneman, 1973). Investors will be pegged by the amount of anchoring value used as initial belief, then make adjustments to the new information received. Anchoring is considered to be very strong as a basic reference so that many people then become dependent on these values (Bloomfield et al., 2003); (Boussaidi, 2013) ; (Wahyuni et al., 2016); (Habbe \& Mande, 2016); (Habbe, 2017); (Sundari \& Habbe, 2018); (Praditha et al., 2020).

Thus, it can be concluded that the negative charge information, the form of information both single benchmark and Multiple Benchmark does not differ in influencing investor decisions which in this case is a prediction of future earnings performance. This is caused by the heuristic factors experienced by investors so that investors are more likely to stick to initial beliefs (anchoring) and revise their beliefs are not much different from their initial beliefs. 


\section{Conclusion}

Belief Adjustment Theory explains that when two information that has different information content such as positive and negative information, investors tend to revise their initial beliefs. In this case, the form of information used is comprehensive information which is a form of Multiple Benchmark accounting information that contains more than one benchmark that consists of past information, present information and future information in the form of Management Guidance.

By using the Multiple Benchmark information form, this research succeeded in proving the existence of a revision of investors' beliefs as described in the belief adjustment theory. Both in the positive and negative information load, investors are proven to revise the prediction of the company's future earnings performance more favorable than the initial value. However, when compared partially, both have different revisions of belief. On the charge of positive information, investors significantly revise with predictions that are far different from their initial values. Meanwhile, on information with a negative charge, investors tend to revise not much different from the initial value. This is due to the influence of the anchoring-adjustment heuristic factor.

The results of this study have implications for the disclosure of accounting information, where investors are known to tend to be pegged to the value of profit / loss transitory which is a benchmark that makes investors tend to revise their beliefs. Besides, comprehensive information disclosure in the form of Multiple Benchmark information is also proven to be able to influence investor decisions. So that issuers can make information patterns as needed in the presentation of accounting reports. For investors, this research has implications in terms of cognitive psychology where investors tend to be pegged at the initial value because they experience heuristic anchoringadjustment. This congestion causes a heuristic bias in decisions taken, so that investors can improve their cognitive psychology to reduce the possibility of bias in faithful decisions taken.

\section{References}

Anggraeni, A., \& Almilia, L. S. (2017). Model Belief Adjustment dalam Pengambilan Keputusan Investasi Berdasarkan Informasi Nonakuntansi. Jurnal Ekonomi Dan Bisnis, 20(1), 149. https://doi.org/10.24914/jeb.v20i1.923

Bahník, Š., Englich, B., \& Strack, F. (2017). Anchoring Effect. In Rudiger F. Pohl (Ed.), Cognitive Illusions: Intriguing Phenomena in Judgement, Thinking and Memory (Second Edition. London: Routledge.

Bloomfield, R., Libby, R., \& Nelson, M. W. (2003). Do Investors Overrely on Old Elements of the Earnings Time Series? Contemporary Accounting Research, 20(1), 1-31. https://doi.org/10.1506/N8T8-9QR7-YUCX-91X2

Boussaidi, R. (2013). Representativeness Heuristic, Investor Sentiment and Overreaction to Accounting Earnings: The Case of the Tunisian Stock Market. Procedia - Social and Behavioral Sciences, 81(1974), 9-21. https://doi.org/10.1016/j.sbspro.2013.06.380

Fiegenbaum, A., Hart, S., \& Schendel, D. (1996). Strategic Reference Point Theory. Strategic Management Journal, 17(3), 219-235. https://doi.org/10.1002/(sici)1097- 
0266(199603)17:3<219::aid-smj806>3.3.co;2-e

Habbe, A. H. (2017). Estimation Error of Earnings Information: A Test of Representativeness and Anchoring-adjustment Heuristic. International Journal of Economics and Financial Issues, 7(1), 224-233. https://dergipark.org.tr/ijefi/issue/32002/353177\#article_cite

Habbe, A. H., \& Mande, H. (2016). the Effect of Information Sequential and Personality on the Investor Belief Revision (an Experimental Study in Decision Making). PONTE International Scientific Researchs Journal, 72(10), 150-166. https://doi.org/10.21506/j.ponte.2016.10.13

Han, J., \& Tan, H. T. (2007). Investors' reactions to management guidance forms: The influence of multiple benchmarks. Accounting Review, 82(2), 521-543. https://doi.org/10.2308/accr.2007.82.2.521

Hartono, J. (2004). How, Why and When Investors Revise Their Beliefs to Company Information and Their Implications to Firm's Announcement Policy. ANDI.

Hogarth, R. M., \& Einhorn, H. J. (1992). Order effects in belief updating: The belief-adjustment model. Cognitive Psychology, 24(1), 1-55. https://doi.org/10.1016/0010-0285(92)90002-J

Krische, S. D. (2005). Investors 'Evaluations of Strategic in Earnings Announcements. 80(1), 243-268. https://doi.org/10.2308/accr.2005.80.1.243

Ordóñez, L. D., Connolly, T., \& Coughlan, R. (2000). Multiple reference points in satisfaction and fairness assessment. Journal of Behavioral Decision Making, 13(3), 329-344. https://doi.org/10.1002/1099-0771(200007/09)13:3<329::AID-BDM356>3.3.CO;2-H

Praditha, R., Haliah, H., Habbe, A. H., Rura, Y., \& Anwar, A. I. (2020). Accounting Information Disclosure: Single versus Multiple Benchmark. Hasanuddin Economics and Business Review, 4(1), 22-28.

Richie, M., \& Josephson, S. A. (2017). Quantifying Heuristic Bias: Anchoring, Availability, and Representativeness. Teaching and Learning in Medicine, 30(1), 67-75. https://doi.org/10.1080/10401334.2017.1332631

Schrand, C. M., \& Walther, B. R. (2000). Strategic Benchmarks in Earnings Announcements: The Selective Disclosure of Prior-Period Earnings Components We have received helpful comments from Ray Ball. The Accounting Review, 75(2), 151-177.

Sundari, S., \& Habbe, A. H. (2018). Heuristic of Representativeness and Anchoring-Adjustment in Budgeting. 8(4), 52-60. https://doi.org/10.6007/IJARAFMS/v8-i4/5185

Wahyuni, S., \& Hartono, J. (2012). Reminder Effect and Anchoring-Adjustment in earnings announcements: Implementation of Prior-Period Benchmark Disclosure Strategy. Journal of Indonesian Economy and Business, 27(3), 390-405.

Wahyuni, S., Hartono, J., \& Nahartyo, E. (2016). Implementasi Strategi Pengungkapan Informasi Laba Patok Duga Tunggal dan Multipel dalam Rerangka Teori Titik Acuan Ganda. Simposium Nasional Akuntansi XIX, 1-30.

Wardhani, D. A. K., \& Almilia, L. S. (2012). the Predictive Power of Earnings and Cash Flows (Testing At the Every Stage of Company'S Life Cycle). The Indonesian Accounting Review, 3(01), 9. https://doi.org/10.14414/tiar.v3i01.208 